\title{
Global Economic Governance After the Crisis
}

\section{Citation}

Frieden, Jeffry. 2012. Global economic governance after the crisis. Perspektiven der Wirtschaftspolitik 13(suppl. s1): 1-12.

\section{Published Version}

doi:10.1111/j.1468-2516.2012.00391.x

\section{Permanent link}

http://nrs.harvard.edu/urn-3:HUL.InstRepos:10886847

\section{Terms of Use}

This article was downloaded from Harvard University's DASH repository, and is made available under the terms and conditions applicable to Open Access Policy Articles, as set forth at http:// nrs.harvard.edu/urn-3:HUL.InstRepos:dash.current.terms-of-use\#OAP

\section{Share Your Story}

The Harvard community has made this article openly available.

Please share how this access benefits you. Submit a story.

Accessibility 
June 2012

\title{
Global Economic Governance After the Crisis
}

\author{
Jeffry Frieden \\ Harvard University \\ Department of Government
}

This paper is based on a lecture delivered to the German Economics Association (Verein für Socialpolitik) in Frankfurt, September 5, 2011.

JEL No. F02, F33, F53, F55, H11, H12, H87 


\begin{abstract}
It has become common to insist that contemporary international economic problems require a great increase in the extent of "global governance" of economic affairs. This desire, understandable as it may be, confronts a series of major obstacles. First, the normative case for global governance is more difficult to justify, and more complex, than is usually recognized, and requires consideration of both economic and politicaleconomy principles. Second, in practice, the provision of governance at the supranational level - that is, of international public goods - depends largely on support from powerful and concentrated interests. Third, this dynamic means that the types of international public goods provided, the way they are provided, and the governance structures erected around them are biased in favor of their strongest supporters, and are therefore likely to be a source of continuing controversy.
\end{abstract}


Ever since the Great Recession began late in 2007, there have been continual and insistent calls for greater global governance. These calls have come from an unprecedented variety of quarters - national politicians, financial leaders, international institutions, non-governmental organizations. Within Europe, the trend takes the form of calls for more intensive, or more effective, governance in the European Union (or the eurozone).

In historical perspective, this is quite a remarkable development. A couple of decades ago, only cranks were calling for what is effectively the beginnings of a world government. ${ }^{1}$ For "global governance" in any meaningful sense involves the provision of government-like services - in particular the supply of public goods - at the international level. In the absence of global government, it is hard to see how this is anything but a pipe dream.

Yet calls for greater global governance have in fact been associated with an impressive series of attempts to provide government-like services at the global level. Supranational agencies, such as the International Monetary Fund (IMF) and the European Union (EU), have managed trillions of dollars in debt workouts in ways previously administered almost exclusively by national governments (or, at times, among private agents). The Bank for International Settlements has supervised a level of financial regulatory harmonization that would have been unthinkable thirty years ago. 
There have been increasingly serious discussions about the provision of regional, or even international, lender of last resort facilities by supranational organizations ranging from the ECB (which already does this, in practice if not in theory) to the IMF.

I confess to being something of a skeptic about the current craze for global governance. In part this is because of the looseness with which the term is used, meaning many things to many different people. In part, my skepticism is due to a belief that most discussions of the matter are not grounded in firm normative principles that clearly establish when "global governance" is necessary or even desirable. And my further skepticism can be ascribed to a belief that in practice global governance is difficult to achieve, and likely to be achieved in ways that do not fully deliver on its promise.

In this essay, I suggest that we think more rigorously about global governance on both normative and positive dimensions. Normatively, we have to ask whether it is desirable, and if so under what conditions. Positively, we would like to know what explains why global governance has emerged where it has, and what its future is likely to be. Along these lines, I make three simple points. First, the normative case for global governance is more difficult to justify, and more complex, than is usually recognized, and requires consideration of both economic and political-economy principles. Second, in practice, the provision of governance at the supra-national level requires far more than a convincing normative argument. In fact, international public goods are typically 
only provided when powerful and concentrated interests - private or public - favor them. Third, this dynamic means that the types of international public goods provided, the way they are provided, and the governance structures erected around them are biased in favor of their strongest supporters, and are therefore likely to be a source of continuing controversy.

I start by discussing the normative case for dramatically enhanced international cooperation, up to and including the creation of a supranational institutionalized authority to provide international public goods. I then analyze why we see demands for global governance (or its provision) where we do, and what this implies about the future possibilities of more. Throughout I use two quasi-federal experiences, the United States and the European Union, as something of a benchmark. They illustrate circumstances in which government-like authority has (or has not) been delegated from sub-federal to federal units, and provide something of a check on flights of fancy that are not grounded in actual experience.

\section{Global governance galore}

Politicians, analysts, journalists, and others have been paying unprecedented lip service to the desirability of global governance, especially in the aftermath of the Great Recession that started in 2007. The crisis spread very rapidly from country to country, soon engulfing virtually the entire world; and its effects are still being felt, for example in the ongoing sovereign debt problems of the eurozone. The spread and persistence of 
the crisis provided many examples of failures of cooperation, and of opportunities for cooperative behavior that were not taken.

The sense grew that the global response to the crisis was lacking, and that national governments had been unable to manage an authoritative coordination of their policies that could have mitigated the effects of the crisis. Similar sentiments spread among members of the European Union, as the Union appeared hamstrung in its ability to address the crisis even as the project of Economic and Monetary Union itself seemed threatened. As frustration with the inability of national governments to resolve the global economic problems grew, calls for greater global governance proliferated.

But is the failure of one level of government really an argument for adding another level? If national government responses to the crisis were inadequate, what would lead us to expect that global or regional governance structures - which, after all, would be aggregations of national governments - would do any better? Many of those who invoked the need for greater global governance seemed simply to be dissatisfied with national policies - their own or those of other countries - and to hope that some new international or supranational institution would set things right. But there is no foundation for the expectation that some global governance ex machina, as it were, would perform any differently than national governments. To expect it to do so is to fall into the simple-minded, and easily disproven, belief that if only a better solution were available, it would be adopted. Realism, both theoretical and empirical, requires us to 
think harder about whether and under what circumstances we might in fact want more global governance.

\section{The normative case for greater global governance of the international economy}

What is typically meant by "governance" is the provision of government-like functions, either by systematic instutionalized inter-governmental cooperation something going beyond casual and temporary measures -- or by supranational institutions such as the IMF, the BIS, and (within Europe) the ECB. We can leave aside the form that global governance structures might take - whether they require institutions with buildings and addresses, or only commonly agreed-upon rules, for example - to focus on a more general, abstract notion. Governance is taken to mean the authoritative provision of government-like functions; there is some decision rule by which choices are made, and some way of enforcing rules.

A common normative argument for the need for greater global governance parallels that of the argument for national government provision of public goods. There is, for example, a familiar parable about the evolution of the American federal union.

When the country was young and markets were local, regulation was carried out at the state, county, and municipal level. There were few externalities that fell outside these boundaries, for virtually everything was produced and consumed in a restricted area. As markets became national over the course of the nineteenth century, the persistence of dozens - even hundreds - of different regulatory agencies at the state, country, and 
municipal level became untenable. A national market required national government regulation, which led to the rise of the Federal regulatory state. ${ }^{2}$ Just as the creation of national markets required national governance structures, so by extension does the development of truly global markets - especially financial markets - require some form of global governance.

However, the case for global governance is not the same as the case for national government action, which is typically justified as providing public goods or correcting market failures. For there are, precisely, national governments to carry out these functions. National market failures can be corrected by national governments; national public goods can be provided by them. There are no "global" markets in the abstract; all market activity takes place in some national jurisdiction (or series of jurisdictions). To justify international governance, there has to be something that national governments will not adequately supply.

The principal justification for global governance must be that there are externalities that are not internalized by national governments, and that this makes everyone worse off. That is, there must be failures of national governments to pursue policies that necessarily involve cooperation or coordination with others. This implies that the justification for global governance must inherently be a political and political economy justification, because it involves expectations about government policies. It is not enough to note that there are external effects of any one nation's actions; it must also 
be the case that, left to their own devices, national governments would be unwilling or unable to address the problem. This is what I mean when I say that the externalities have to be political, that is, there has to be some political incentive for governments not to internalize their impact, and not to consider the effects of their actions on other nations and governments.

Trade protection, for example, would not seem to qualify as requiring global governance: governments are well aware of the impact of their protectionist policies on others, and they consider this - in particular, the threat of retaliation - in making their own policies. In a purely economic sense, one country's trade protection could impose negative externalities on another. However, in a political economy sense, in which the government must take into account the responses of other governments, in which exporters may be affected by retaliation and therefore moved to influence their own government to avoid protection - in short, where the political process, both international and domestic, serves to internalize the externalities - it is hard to see how there is any demonstrable need for supranational governance to internalize the externalities in trade policy.

This is not to say that there are no areas in which one could make an argument for the desirability of such global governance structures, or at least systematic international cooperation. In fact, the example of trade policy may be instructive. While national political processes may lead national governments to internalize the external 
effects of their trade policies, there may still be scope for something that goes beyond simple bilateral agreements among governments. It may be useful, as has been argued, to have transparent and commonly agreed-upon rules, with clear escape clauses; or a way to bind politicians in the eyes of domestic publics; and it also may be important to have some commonly accepted adjudication and arbitration mechanism. These may in fact be provided by the WTO. ${ }^{3}$

Another example, that of national exchange-rate policy, may help clarify how we can think about the political economy externalities instead of the purely economic ones. Typically we see national currency policy as appropriately national, with no pecuniary externalities. If a country's currency is "undervalued," that is its own decision and its own problem. The policy has domestic distributional effects, by helping tradables producers and hurting consumers; it also generously provides foreigners with cheaper goods. This, however, it the purely economic view. If we consider the broader political economy, a country's substantially depreciated currency can in fact impose costs on other countries' governments, and may in fact have negative effects on the broader international trading system. Studies have established that a one standard-deviation currency appreciation (the flip side of another country's depreciation) is associated with between a $20 \%$ and $50 \%$ increase in protectionist anti-dumping filings and findings. ${ }^{4}$ So national currency policy can lead to trade conflicts that make all worse off. 
All of this is simply to say that there are cases in which one can make a normative argument for greater global cooperation, even governance. But the argument must be made carefully, and all too commonly it is not. I can think of two prominent examples in which the case for greater global governance is rarely made in a way that is convincing, at least to me.

The first is in the case of global imbalances. It is common for policymakers, observers, and others to argue that the existence of global macroeconomic imbalances requires some form of global governance; the idea has been enshrined in institutional attempts, such as at the IMF to engage in various forms of surveillance. There are some reasonable arguments for the proposition that these imbalances impose externalities on other countries, and on the international economic order more generally. However, the case is not obvious: after all, what we now call "global imbalances" used to be called international capital movements, and have long been regarded as voluntary and desirable.

Often, the call for global governance of global imbalances simply expresses the desire by some to force national governments to change their policies. Those disturbed by the fact that a particular national government won't rein in its current account deficit come up with the idea that we need to get some global police force do so. Typically, there is no clear sense of what the welfare argument for this sort of intervention might be - let alone its practical possibilities. Instead, those concerned about global imbalances 
- or about a particular country's imbalance - want to call upon a higher power, even one that does not exist, to force a change in government policy. There may be good reasons why such supranational action is desirable, and good arguments for the desirability of some form of governance over global macroeconomic imbalances. However, the simple existence of stubborn current account deficits, over the objections of some observers, is not in itself an argument for an international deficit-reduction strike force to impose adjustment.

A second such questionable argument has to do with demands for greater governance of fiscal policy within the eurozone. It often seems to an outsider that calls for "governance" in the European Union are little more than poorly disguised attempts to insist that German (or more broadly Northern European) preferences be imposed on other members of the EU (or at least the eurozone), to rein in undesirable levels of debt accumulation. I suppose that a counter-proposal from the peripheral (debtor) countries might be for governance structures to rein in undesirable levels of asset accumulation by Northern Europeans; if this seems absurd, note that it is roughly what many in the United States and elsewhere are calling for with respect to the surplus countries of East Asia, especially China.

The common justification for this view, that monetary union requires fiscal centralization, is logically flawed. If the sub-units of a monetary union (states, provinces, countries) are charged appropriately for their borrowing, there is little or no 
substance to the argument that they are imposing externalities on other sub-units in the union. The problem in the eurozone was that the commitment not to bail out member states that got into trouble was not credible.

The experience of the United States is often invoked, but inaccurately. American states are charged different interest rates for their borrowing - over the past few years there have been times when California has paid more than 160 basis points above the Treasury rate on its five-year bonds, while Massachusetts has at times paid nearly 100 basis points below the Treasury rate. There is an often-repeated fiction that the states' fiscal autonomy works because there are strict balanced-budget amendments; but, again, this is inaccurate. The balanced budget requirements vary enormously, and some are close to being fictitious: for example, many only require that the governor present a balanced budget, and others include receipts from borrowing as revenues. The character of the fiscal institutions is considered by lenders to the states, to be sure, but the reason the system works is that since the 1840s the no-bailout commitment has been credible, and the states are charged according to their perceived creditworthiness. ${ }^{5}$ Nor do the federal automatic stabilizers, which only replace a small portion of lost income in times of crisis, go very far toward explaining the outcome. The American states do quite well in a single market and a monetary union without centralized fiscal control; they do so with a clear distribution of responsibilities between the states and the federal government. 
It may well be that fiscal centralization or coordination would have a positive impact on macroeconomic conditions in the eurozone, or that some other mechanism to limit government deficits could be desirable. But this is not, in itself, a strong normative argument for greater fiscal governance. One could just as easily make the case for fiscal decentralization to ensure that national governments bear the costs of their own fiscal policies.

Let me make clear that I am not arguing in favor of irresponsible fiscal policy, unproductive borrowing, or reckless lending. However, the existence of bad policies is in itself not a justification for greater, more centralized, international authority over economic (or other) policy; it should, first and foremost, prompt us to try to get governments to pursue better policies at the national level. While there may be uninternalized externalities in both of these instances, and in others in which calls for greater global governance are common, I do not think that this case has been made strongly or convincingly enough.

We need to examine the case for moving policy authority up one level with great care, whether the levels in question are local, sub-national, national, regional, or global. The arguments for this sort of delegation upward to the global level, in particular, need to be rigorous and theoretically grounded to be convincing. Simply because we don't like the outcome that the political process delivers at the national level does not mean that there is a normative case for shifting it to the international level. 
Nonetheless, even when the normative argument for global governance is strong, it may be irrelevant to determining what actually happens. Indeed, a commonplace of analytical political economy is that normative arguments rarely have much impact on observed policy outcomes. The fact that the eurozone was not an optimal currency area; that no country in the world pursues unilateral free trade; the persistence of agricultural subsidies - all bear witness to the fact that political realities are often more powerful than welfare considerations. It may be the case that some positive welfare effects are a necessary (or at least a very common) source of pressure to develop global cooperative structures; but they are surely not sufficient. What, then, explains why there has in fact been more global cooperation - even more institutionalized cooperation, that is, governance - in some times, places, and issue areas than in others?

\section{The positive analysis of global governance of the international economy}

I am not so cynical to believe that politicians are completely indifferent to the impact of policy on aggregate social welfare; indeed, in standard political economy models the policymaker considers the impact of policy on both special interests and the broad electorate. ${ }^{6}$ Nonetheless, even the most desirable policy needs some interested parties to promote it - be they concentrated social groups, political entrepreneurs, or simply the electorate.

Aggregate social welfare does not vote. For politicians to take policy effects into account, the policies need to have a direct or indirect impact on how constituents will 
reward or punish the politicians. ${ }^{7}$ The constituents in question might be the broad electorate, or special interest groups, or some combination thereof. The job of a policymaker is to act in line with the preferences of his constituents, which includes concentrated special interests.

In this context, I believe that public goods are most likely to be provided if powerful interest groups press for them. There are several theoretically grounded ways to think about this. It could be that the public good is a joint product with a private good; this might be the case of the public good provided by the establishment of an independent central bank, where the bank was structured so as to provide particular benefits to the financial sector. ${ }^{8}$ It could be that the public good has differential benefits, providing substantial benefits to some but only trivial benefits to others. And it is certainly the case that most public goods can be provided in very different ways, with potentially very different distributional implications. Pollution control is a public good; but it can be implemented in ways that are particularly costly to polluting firms, or that pick up their tab. In the words of a classic article by Stephen Krasner, much of the politics of public goods provision is "life on the Pareto frontier," along which powerful interests battle over the ways and means the public goods are structured and provided..$^{9}$

We can go back to the American parable mentioned above for an illustration. Recent scholarship indicates that it was not just the functional need for national regulation of national markets that explains the Progressive-era growth of Federal 
power. Increasingly important national corporations resented having to deal with 50 or more local regulators, especially inasmuch as many of the state regulators were particularly subject to populist pressures. They pushed for bumping regulation up to the Federal level in part because it would have reduced their costs, and in part because they expected Federal regulators to be more sympathetic to them than state and local regulators. ${ }^{10}$ We can accept the notion that national regulation was a public good; but we should also recognize that the public good was achieved due at least in part usually large part - to demands from powerful interest groups concerned primarily about its impact on their well-being. ${ }^{11}$

This general principle applies also at the international level. For national policymakers to have strong enough incentives to want to create supranational governance structures, there must be some demand for them from their national constituencies. And since the electorate in most societies is largely indifferent to, or ignorant of, these international issues, there is reason to believe that the principal pressures will come from concentrated interests.

There is an extraordinarily wide variety of ways of providing global public goods or internalizing externalities at the international level, many of which have very different distributional effects. It is precisely these distributional effects that gives powerful interests an incentive to invest time, energy, and thought to their design, and to exert pressure for combinations that favor them. However, this also means that the 
way in which global issues are addressed is typically biased in favor of the powerful interests that want them most. To be sure, for there to be broad enough consent for the policy, those who may be less favored by the particular form the governance structure takes must accept that a public good that differentially benefits somebody other than themselves is better than no public good at all. But still the bias exists.

The implication is that the emergence of international governance structures requires much more than some demonstration of the existence of the public good itself; there must be powerful, concentrated, private benefits to the process. I think that this is crucial to understanding the great upwelling of discussions about global governance, as more and more powerful private actors become more and more international, with more at stake in the international realm and a more focused desire to see some of these problems resolved. I also think that the role of these private concerns, and private demands, is crucial to explaining the form and content of changes in the ways in which international institutions and inter-state cooperative ventures deal with global economic issues.

Some examples illustrate the point. First we can look at the resolution of sovereign debt crises - drawing on the ample literature on past crises, rather than current events. It is well understood that some means to enforce the borrower's commitment to pay is beneficial to both lenders and borrowers: without such a commitment device, there might be no lending. This is the reason for orderly 
bankruptcy proceedings in domestic finance, which serve the interests of all parties (given the debtor's bankruptcy). The same logic holds at the international level, with the clear difference that there is no real scope for meaningful third-party enforcement, especially as the possibilities of posting collateral or seizing assets are very limited.

For international lending to work, some way has to be found to mitigate this commitment problem; debt contract enforcement in this environment is a public good, or close to it, inasmuch as well-functioning international financial markets are beneficial to all. ${ }^{12}$ Of course, there are powerful private interests that have a concentrated and direct interest in ensuring contract enforcement, especially within the creditor community.

In fact, over the course of the past couple of centuries, creditors and debtors have devised a variety of forms of international collaboration to try to deal with the problem. ${ }^{13}$ Throughout most of the nineteenth and early twentieth century, there was a joint public-private arrangement organized around "creditor committees," typically grouping the creditors of different nations in a common organization to negotiate with the debtor, and to oversee the implementation of the eventual agreement. Creditor governments were often involved, either directly or indirectly, in support of their own investors. In the interwar years, much of this coordination was taken up by the League of Nations Economic and Financial Committee, which oversaw a series of debt workouts in Central and Eastern Europe; the Bank for International Settlements was 
established in 1930 to do something similar with respect to Germany. And since the 1970s, the International Monetary Fund has largely served this purpose in sovereign lending, providing a coordinating mechanism around which creditors can converge and bargaining with debtors over terms of both adjustment and (implicitly) debt restructuring.

These arrangements are examples of clear Pareto improvements over what might prevail in the absence of any such mechanism - which could well be little or no international lending to developing countries at all. But it is just as certainly the case that in most instances, such mechanisms have been biased in favor of creditors - a fact that has been the source of many debtor-country complaints. However, the systems have largely worked because even the most belligerent of debtors recognizes that some arrangement to keep money flowing, even a biased one, is better than none at all. This example demonstrates two points made above: it can take the concentrated pressure of a special interest (in this case creditors) to lead to the provision of an international public good; and, as a result, the public good may be provided in a way that is biased in favor of the special interest that promoted its provision.

Financial regulatory harmonization has similar characteristics. The variety of efforts undertaken under the auspices of the BIS, in particular the Basel agreements, almost certainly have something of the nature of an international public good. ${ }^{14}$ Certainly they limit, while not eliminating, the possibility that financial institutions 
could take advantage of major regulatory distinctions to arbitrage across different regimes in ways that could exacerbate international risks. Whatever their limitations, the Basel agreements represent a voluntary, coordinated convergence on a range of regulatory arrangements - something of a minor triumph for international cooperation, perhaps even global governance. And yet systematic analysis has shown that the nature of the agreements was heavily influenced by the concerns of powerful special interests with a strong desire for specific features of the regulatory accords, in particular by the American and British international financial communities. ${ }^{15}$

A counter-example is that of foreign direct investment (FDI). There have been proposals for some form of multilateral agreement on international investment for over fifty years, but they have led nowhere. ${ }^{16}$ One could imagine a normative case for such an international agreement on FDI: some independent assurance of contractual compliance is welfare-improving for both the host country and the investor, and this can only be provided at a supranational level. But virtually nothing has been done at a global level; what public action has been taken has been almost exclusively with bilateral investment treaties. ${ }^{17}$ My surmise would be, in line with the above, that the principal private actors involved in FDI - especially the major multinational corporations - are perfectly happy to work out arrangements of their own with host countries on a case-by-case basis. Bilateral agreements help them out, by drawing their home governments into the mix in case of conflict, but the problems faced by direct 
investors are typically firm-specific, and can be addressed by firm-specific negotiation. So nothing has been happened; no global public good has been demanded by powerful interests, and so none has been supplied.

We can return to global macroeconomic imbalances for another example of a realm in which there has been much talk about global governance, but little action. These have received massive attention over the past decade, in no small measure because they are widely believed (including by me) to be at the root of the global crisis that began in 2007 and whose effects continue to bedevil both the United States and Europe.$^{18}$ Despite my skepticism, expressed above, there are certainly many observers who believe the behavior of both surplus and deficit countries has imposed significant externalities on other countries. Certainly it is the case that since about 2006, the IMF and some other international economic organizations have attempted to focus attention on the problems these imbalances can cause, and have attempted to stimulate more global governance of the issue. Yet we are probably no closer to any meaningful international collaboration on the subject than we were ten years ago, let along any form of global governance (or even European governance).

But where would we expect to find the origin of meaningful political pressure on governments to create some international cooperative mechanism to address global imbalances? The lenders, in surplus countries, have strong interests in continuing to lend - in the case of China, for example, surpluses are at the core of the government's 
development strategy. The borrowers, in deficit countries, have equally strong interests in continuing to borrow. In some cases, to be sure, they have now been frozen out of capital markets, but they surely would like to return someday; in other cases, such as that of the United States, borrowing continues to provide the public and private sectors with resources they value and do not want to give up. The negative effects will presumably be borne by taxpayers and future generations; taxpayers are too diffuse a force, and future generations do not vote (yet). Neither deficit nor surplus countries are willing to accept that forcing adjustment upon them is a price worth paying for the (potential) public good of international financial stability. The absence of concentrated interests in reversing course implies that there is little prospect of the emergence of serious coordination of macroeconomic policies to avoid a recurrence of the imbalances of the past decade. If these imbalances do subside, it will almost certainly not be because governments collaborate to smoothly address the problem, but rather because purely economic forces compel adjustment, perhaps brutally.

The potential expansion of global governance is not best understood as a function of general realization of its desirability. Instead, it is likely to be the result of the interaction of some general welfare considerations - which are in themselves a weak reed - and, more important, concentrated demands and pressures from powerful interests that stand to benefit most from the provision of these international public goods. 
This creates an implicit tension. Governments have incentives to work together to supply global public goods when powerful, concentrated interests want them to be provided; this is likely to make the way in which the public goods are structured particularly favorable to the concentrated interests. And this in turn can make the global ventures politically unpalatable, inasmuch as they appear to benefit primarily powerful interest groups. To take an American example, the involvement of the U S government in financial rescue operations during the Mexican crisis of 1994 and the Asian financial crisis of 1997-1998 led to a powerful, nearly immediate backlash on the part of American public opinion - and a major Congressional initiative that has limited the ability of the Executive to act to carry out such rescues. ${ }^{19}$

Global governance is no panacea for political controversy over international economic issues. It cannot eliminate disagreements among countries, or within countries. Indeed, to the extent that global governance is used as a way to try to insulate economic policymakers from domestic pressures - as many members of the U S Congress believed was the case with the international financial bailouts of the 1990s, and many Europeans seem to believe about current policies toward the eurozone sovereign debt crisis - there is a serious risk of a political backlash. There are many who felt that even if there was some justification for the financial rescue packages, they were structured in ways far too beneficial to creditors, and were enacted with far too little 
attention to domestic distributional effects. Delegation to an international institution, or to inter-state cooperative ventures, is not a substitute for politics.

Where are there likely to be strong prospects for enhanced global governance, then? In my view, first and foremost in issue areas where there are powerful private interests, in powerful nations, who would like to see it happen. Where one or both of these conditions is lacking, no matter how compelling the welfare case or how elegant the economic analysis, I think that any movement in this direction is unlikely. Policy is made by politicians, and politicians respond to their constituents - not to abstract appeals to improve aggregate social welfare.

\section{Summing up}

There has been a powerful increase in the apparent desire of policymakers, market participants, and analysts to have national governments delegate more of their responsibilities to supra-national quasi-governmental organizations, or to international cooperative ventures - to global governance. The apparent failures of many national governments to address contemporary economic problems effectively and with alacrity seems to have provoked a yearning for some other level of government to make things better. However, the normative case for such delegation to a higher power is much more restrictive than is commonly understood.

Even where the normative case can be made strongly, policy responds to political pressures that are often orthogonal to aggregate welfare considerations. There 
have been successful attempts to provide certain public goods at the global or regional level. In most instances, it took the active support of powerful concentrated interests with a direct concern for the policy in question to motivate this provision.

Greater global governance may well emerge over time. If so, it is most likely to be where there are powerful private agents who feel that their interests cannot adequately be addressed within the confines of a national state. Nevertheless, the creation of global governance structures - or some enhanced form of international economic cooperation - is not the end of politics; it only shifts it to a higher level, and so raises the stakes. 


\section{Notes}

${ }^{1}$ Indeed, twenty years ago I evinced skepticism about the realism of one academic attempt to argue for the need for more systematic attempts to provide global public goods, in a book review of International Public Finance: A New Perspective on Global Relations by Ruben P. Mendez, published in The American Political Science Review, Vol. 87, No. 4 (Dec., 1993), pp. 1059-1060.

${ }^{2}$ The classic statement of this, with related points about the desire for the modernization of government, is Robert H. Wiebe, The Search for Order, 1877-1920 (New York: Hill and Wang, 1966).

${ }^{3}$ See, just as examples of the enormous literature on the subject, Kyle Bagwell and Robert Staiger, "An Economic Theory of GATT," American Economic Review 89, number 1 (1999), pages 214-48; Jeffrey Kucik and Eric Reinhardt, “Does Flexibility Promote Cooperation? An Application to the Global Trade Regime," International Organization 62, number 3 (2008), pages 477-505; Robert Staiger and Guido Tabellini, “Do GATT Rules Help Governments Make Domestic Commitments?" Economics and Politics 11, number 2 (1999), pages 109-44; and, more generally on international institutions, Lisa Martin and Beth Simmons, "Theories and Empirical Studies of International Institutions," International Organization 52, number 4 (1998), pages 729-57. 
${ }^{4}$ Michael Knetter and Thomas Prusa, "Macroeconomic factors and antidumping filings,"Journal of International Economics 61, No. 1 (2003), pages 1-18; Thomas Oatley, “Real Exchange Rates and Trade Protectionism," Business and Politics 12, No. 2 (2010); and my own "Capital Politics: Creditors and the International Political Economy," Journal of Public Policy, 8, No. 3/4 (July-December 1988).

${ }^{5}$ The literature on the subject is enormous. For a sample, see James Poterba, "State Responses to Fiscal Crises: The Effects of Budgetary Institutions and Politics," Journal of Political Economy 102 (August 1994), 799-821; James Poterba and Kim Rueben, "Fiscal News, State Budget Rules, and Tax-Exempt Bond Yields," Journal of Urban Economics, 50, No. 3 (2001), pages 537-562; and Henning Bohn and Robert Inman, "Balanced Budget Rules and Public Deficits: Evidence from U.S. States," Carnegie-Rochester Conference Series on Public Policy, December 1996, 45, pp. 13-76.

${ }^{6}$ This is the central argument of the canonical Stigler-Peltzman model, of which the more modern version is the Grossman-Helpman model first presented in Gene Grossman and Elhanan Helpman, "Protection for Sale," American Economic Review 84 (1994): 833-850.

${ }^{7}$ I use "constituents" broadly, in the sense of the "selectorate" in to include the politically relevant portion of society: all voters, or all powerful elites, or the military, as the case may be. On the selectorate, see Bruce Bueno de Mesquita, Alastair Smith, 
Randolph M. Siverson and James D. Morrow, The Logic of Political Survival (Cambridge: The MIT Press, 2003).

${ }^{8}$ See, for example, J. Lawrence Broz, International Origins of the Federal Reserve System. (Ithaca: Cornell University Press, 1997).

${ }_{9}^{9}$ Stephen D. Krasner, “Global Communications and National Power: Life on the Pareto Frontier," World Politics Vol. 43, No. 3 (April 1991), pp. 336-366.

${ }^{10}$ See, for example, Richard Sylla, "The Progressive Era and the Political Economy of Big Government." Critical Review 5, No. 4 (1991): 531-557; and, from a very different perspective, Martin Sklar, The Corporate Reconstruction of American Capitalism, 1890-1916 (New York: Cambridge University Press, 1988).

${ }^{11}$ Two applications in the American context are Thomas Gilligan, William Marshall, and Barry Weingast, "Regulation and the Theory of Legislative Choice: The Interstate Commerce Act of 1887" Journal of Law and Economics 32 (April 1989) pages 35-61; and Gary Libecap, "The Rise of the Chicago Packers and the Origins of Meat Inspection and Antitrust," Economic Inquiry 30, No. 2 (April 1992), pages 242-262.

${ }^{12}$ It might be more strictly accurate to say that the general expectation of enforcement of contracts across borders is the public good, rather than a particular commitment device, as one could imagine making the latter excludable. The distinction is not great, especially when the group of creditors and creditor-country governments is largely the same for most or all international lending. 
${ }^{13}$ I have discussed some of these issues in general in Jeffry Frieden, "International investment and colonial control: A new interpretation," International Organization 48, No. 4 (Autumn 1994); see especially pages 586-591.

${ }^{14}$ I would not want to go too far out on a limb in this regard; opinions do vary, and I have no strong ones. But we shall assume public goodness, for the sake of argument. ${ }^{15}$ See, for example, Thomas Oatley and Robert Nabors, "Redistributive Cooperation: Market Failures, Wealth Transfers, and the Basle Accord,"International Organization, 52, No. 4 (1998); and for a somewhat different view, Ethan Kapstein, Governing the Global Economy: International Finance and the State (Cambridge: Harvard University Press, 1994).

${ }^{16}$ For a summary and attempt at explanation, see Jonathan Crystal, "Sovereignty, Bargaining, and the International Regulation of Foreign Direct Investment," Global Society 23, No. 3 (2009), pages 225-243.

${ }^{17}$ Beth Simmons, Zachary Elkins, and Andrew Guzman, "Competing for Capital: the Diffusion of Bilateral Investment Treaties, 1960-2000," International Organization 60, No. 4 (2006), pages 811-846.

18 Those interested in my views on the subject can consult my book with Menzie Chinn, Lost Decades: The Making of America's Debt Crisis and the Long Recovery (New York: W W Norton, 2011).

${ }^{19}$ See, for example, J. Lawrence Broz, “Congressional Politics of International Financial Rescues." American Journal of Political Science 49, 3 (July 2005): 479-496. 